\title{
A NOTE ON FREGE'S AND RUSSELL'S INFLUENCE ON WITTGENSTEIN'S TRACTATUS
}

\author{
RICHARD MCDONOUGH \\ Philosophy / University of Tulsa \\ Tulsa, OK 74104-3189, USA
}

\begin{abstract}
T $\mathrm{n}$ the Preface to the Tractatus ${ }^{\mathrm{I}}$ Wittgenstein acknowledges only Frege and Russell: "I will only mention that I am indebted to LFrege's great [grossartigen] works and writings of my friend $\mathrm{Mr}$. Bertrand Russell for much of the stimulation of my thoughts." 2 Many important commentators have detected a slant towards Frege. Wittgenstein's reference to Frege's "great works" is, prima facie, stronger than his praise for Russell. This has had a profound influence on generations of commentators. Dummett writes, "The Tractatus pays a profound homage to Frege, homage that is pointedly more intense than that paid to Russell."3 Anscombe writes that "His [LW's] relative estimate of [Frege and Russell] comes out in the acknowledgements he
\end{abstract}

' All references to Wittgenstein's Tractatus Logico-Philosophicus [TLP], trans. D. F. Pears and B. F. McGuinness (London: Routledge, 1961), except to the Preface, are by proposition number. All references to Zettel (Los Angeles: U. of California P., 1970) are by paragraph number. All references to Wittgenstein's Culture and Value (Oxford: Blackwell, 1980) and Notebooks, 1914-I6 (New York: Harper \& Row, 1969) are by page number.

${ }^{2}$ The Ogden translation of the sentence, which Wittgenstein approved, reads: "I will only mention that to the great works of Frege and the writings of my friend Bertrand Russell I owe in large measure the stimulation of my thoughts." The original German is: "Nur das will ich erwähnen, dass ich den grossartigen Werken Freges und der Arbeiten meines Freundes Herrn Bertrand Russell einen grossen Teil der Anregung zu meinen Gedanken schulde."

${ }^{3}$ M. Dummett, Frege: Philosophy of Language (London: Duckworth, 1981), p. 662. 
makes to them in the Preface." 4 Carruthers has recently defended an extreme version of this view. He holds that "Frege and Russell, are the only known influences of TLP." Of the two, he regards Frege as the more important: "My impression is that Wittgenstein was partly contemptuous of Russell as a philosopher, whereas Frege he revered from the beginning to the very end ..." (ibid., p. I87n.I4).

Carruthers goes beyond the common observation that the praise for Frege seems greater than that reserved for Russell. First, he wants to use the acknowledgements to exclude other possible influences, besides Frege and Russell, on the interpretation of TLP. Second, he employs the acknowledgements to justify a specifically Fregean interpretation of specific doctrines in TLP (for example, in support of his view that the TLP notion of the thought is a "quasi-Fregean" notion of a mind independent bearer of truth values $\left.{ }^{6}\right) .{ }^{7}$ But the first of these claims is demonstrably false, and the second is unwarranted. With regard to the first claim, at TLP 4.04 Wittgenstein instructs the reader to compare his account of the proposition with Hertz's account of "dynamical" mental systems. There are other known influences on TLP besides Frege and Russell. With regard to the second point, it is simply unwarranted to extend the general praise for Frege in the Preface to the interpretation of specific doctrines of TLP. Finally, I argue that Wittgenstein's acknowledgements do not justify the interpretation that Frege is the paramount influence on the doctrines of the Tractatus. Although I am here more interested in general principles of interpretation than specific doctrines, I illustrate these points with regard to a mentalistic interpretation of Tractatus thoughts (which has connections with both Hertz and Russell).

First, let us look at the sense in which the pair, Frege and Russell, are singled out at the expense of other influences. Consider Wittgenstein's precise wording, and the context, in the acknowledgements. It

4 G. E. M. Anscombe, An Introduction to Wittgenstein's Tractatus (London: Hutchinson, 1959), p. I2.

5 P. Carruthers, Tractarian Semantics (Oxford: Blackwell, 1989), p. 9.

6 "The Tractatus is a pure essay in the theory of meaning, from which every trace of epistemological or psychological consideration has been purged as thoroughly as the house is purged of leaven before the Passover" (Dummett, p. 679).

7 Carruthers, The Metaphysics of the Tractatus (Cambridge, U.K.: Cambridge U.P., 1990), p. II; Tractarian Semantics, p. $8 \mathrm{I}$. is significant that Wittgenstein makes his acknowledgements of Frege and Russell immediately after saying,

I do not wish to judge how far my efforts coincide with those of other philosophers ... the reason why I give no sources is that it is a matter of indifference to me whether the thoughts I have had have been anticipated by someone else.

Carruthers wants to invest the mention of Frege and Russell with just the kind of significance which Wittgenstein warns against. But if Wittgenstein's words are read strictly, then, when he lists Frege and Russell, be is not listing them as sources.

Since the strong word "indebted" occurs directly before Frege's name, there may be a tendency to think that Wittgenstein means to say that his debt is only to Frege. Though the sentence is grammatically ambiguous, it appears that Wittgenstein intends to acknowledge a debt to both Frege and Russell. In any case, his debt is only for the "stimulation" of his thoughts, and stimulation is a weak relation. $X$ 's thoughts can be stimulated by $Y^{\prime}$ 's without its being the case either that $X$ 's views coincide with $Y$ 's or even are a direct reaction to $Y$ 's. Both Frege and Russell are acknowledged, but equally as stimuli, neither as sources for specific views. So a strict reading of the acknowledgements does not justify a general reconstruction of the Tractatus along any kind of precise parallel with either of their views.

Let us now turn to the central claim that the praise for Frege is greater than that for Russell. The real basis for this claim rests on the contrast between Wittgenstein's reference to Frege's "great works" and "the writings of my friend Mr. Bertrand Russell". Whereas the reference to Russell seems warmer, the word "great" is reserved for Frege alone. But what, precisely, about Frege's works is said to be great?

It is significant that years later (in I951) Wittgenstein wrote, "Frege's style of writing is sometimes great" (Culture and Value, p. 87). He continues this theme in Zettel: "the style of my sentences is strongly influenced by Frege. And if I wanted to, I could establish this influence where no one would see it" (\$7I2). It is, therefore, highly significant that the word in the Preface to TLP translated by both Ogden and by Pears and McGuinness as "great" (grossartigen) is properly translated as "grand", "magnificent" or "sublime". This is, roughly, a 
term of aesthetic praise. One might, for example, say of a mathematical proof that it is "grossartigen" (beautiful) - and that is independent of considerations of truth. Similarly, one might say of Plato's Republic that it is "grossartigen", by which one would mean to emphasize its monumental character in the history of philosophy - even though one cannot agree with it.

This is further supported by the fact that Wittgenstein uses the word "Werken" for Frege's works, whereas he uses the word "Arbeiten" to refer to Russell's. Both can be rendered in English by the word "works". But the two German words have very different connotations. Pears and McGuinness translate the latter as "writings". But "Arbeiten" does not mean writings at all. Whereas "Werke" suggests an action, deed, or performance, "Arbeiten" suggests labours or toils. There is no doubt that by his careful choice of these specific words Wittgenstein intended to register a contrast between Frege's performance and Russell's labours. The former suggests an aesthetic reaction, the latter admiration for Russell's unparalleled labours and productivity.

The point is not, of course, that Wittgenstein was not also influenced by Frege's doctrines. I take it as obvious that he was. The point is that when this the case (e.g., at 3.318 where Wittgenstein states that he agrees with Frege and Russell that a proposition is a function of the expressions contained in it), this must, and can, be determined by a detailed examination of the specific text involved, not smuggled in a priori via the acknowledgements. The belief in a privileged Fregeaninfluence is a mythology built on the English translation, whereas the careful choice of words in the German text indicates that Wittgenstein intended to express his reaction to the different kinds of impact these works had on his life (in a broad sense), not a commitment to their philosophical views per se.

Carruthers forgets, first, that Wittgenstein regarded himself as an artist as well as philosopher. Wittgenstein was obsessed with stylistic questions, as well as questions about the origin of his own style. ${ }^{8}$ Second, Carruthers does not take account of the fact that Wittgenstein sees Frege as a great stylist - a trait not normally associated with Frege. Wittgenstein's acknowledgement of a stylistic debt to Frege illustrates

${ }^{8}$ See Culture and Value, pp. 3, 37, 39, 53, 60, 71, 76, 78, 87, etc. the fact that he and Frege are not simply philosophers in a narrow sense, but are complex multidimensional members of various intellectual traditions-and that a similarity along one axis can easily be mistaken for a similarity in another. More generally, the failure to remember that philosophers can represent multiple cultural traditions can lead to systematic distortions in the interpretation of the history of philosophy.

Third, whereas Wittgenstein only saw Frege's finished productions, he himself personally observed, even participated in, Russell's labours, and had some appreciation for the toll that these exacted on Russell. It is therefore only natural that Wittgenstein would wish to comment on this expression of Russell's character and its impact on his own life.

It is in this context that one should recall my earlier remark that, if Wittgenstein is to be taken at his word, then he is not, in the Preface, acknowledging Frege and Russell as sources. The point may have seemed to be far fetched at first hearing. But when taken in connection with the precise wording in the German text, his personal relationship with Russell (but not with Frege), and his later repeated praise for Frege's style, one is reminded that writers use acknowledgements for many purposes. Indeed, one has the pleasure of making kinds of comments in the acknowledgements about the human dimension of the shared enterprise which would be out of place in a discussion of the doctrinal content of the text proper.

Fortunately, there is no necessity to speculate about Wittgenstein's evaluation of his doctrinal influence, for, years later, in 1931, near the time of his return to philosophy, Wittgenstein addressed the issue of influence directly,

I don't believe I have ever invented a line of thinking, I have always taken one over from someone else. I have simply straightaway seized on it with enthusiasm for my work of clarification. That is how Boltzmann, Hertz, Schopenhauer, Frege, Russell, Kraus, Loos, Weininger, Spengler, Sraffa have influenced me. (Culture and Value, p. 19)

Wittgenstein cannot be referring to his later philosophy, since by I93I, the only view which he had produced was that of his Tractatus. Frege is mentioned here, but only in the middle of a group of highly diverse figures, with no special distinction implied over Russell, or, for that matter, the other figures. 
I illustrate these points with reference to the TLP notion of the thought. Whereas Carruthers wants to invoke the a priori slant towards Frege in support of his interpretation that Tractatus thoughts are quasi-Fregean mind-independent bearers of truth-value, Wittgenstein himself tells us at TLP 4.04 to "Compare" his view of the proposition "with Hertz's Mechanics on dynamical models". In the indicated section, Hertz writes,

The agreement between mind and nature may ... be likened to the agreement between the two [material] systems which are models of each other, and we can even account for this agreement by assuming that the mind is capable of making actual dynamical models of things, and working with them. ${ }^{9}$

Since 4.04 is a comment on 4 ("A thought is a proposition with a sense"), Wittgenstein is here indicating that one ought to compare his notion of thought with Hertz's notion of "a mental-picture". ${ }^{\text {IO }}$ Indeed, there are many striking parallels between Wittgenstein's and Hertz's respective notions of a picture. ${ }^{I I}$

Furthermore, this reveals a link to Russell's views. In his Philosophy of Logical Atomism lectures, completed in the same year (1918) as the Tractatus, and which Russell says "are very largely concerned with explaining certain ideas which I have learnt from my friend and former pupil Ludwig Wittgenstein" ( $L K$, p. I77), Russell, in most unFregean spirit, wrote: "I think that the notion of meaning is always more or less psychological, and that it is not possible to give a pure logical theory of meaning" (p. 186). We also know that in 1919, in correspondence, Russell asked Wittgenstein about the constituents of Gedanke, and that Wittgenstein replied that a Gedanke consists of "psychical constituents" (Notebooks, pp. 129-30). Further, in the same year (1919), Russell published his essay "On Propositions: What They Are and How They Mean", in which he develops the view that the possibility of having a mental component "makes the essence of the

${ }^{9} \mathrm{H}$. Hertz, The Principles of Mechanics (New York: Dover, 1956), p. 177.

to P. Hacker, Insight and Illusion (Oxford: Clarendon P., 1972), p. 4n.I; A. D. Wilson, "Hertz, Boltzmann and Wittgenstein Reconsidered", Studies in History and Philosophy of Science, 20 (1989): 245-64 (at 250, 258, etc.)

"J. Griffin, Wittgenstein's Logical Atomism (Oxford: Clatendon P., 1964), p. 99 'meaning' of the words" ( $L K$, p. $\left.302^{\mathrm{r} 2}\right)$. Further, Russell's account of the mental component of meaning bears striking analogies with the picture theory of meaning in the Tractatus. ${ }^{13}$ One can disagree about who influences whom more, but it is clear that in this period Wittgenstein and Russell were engaged in continuous discussion concerning the nature and role of a psychological account of propositional meaning. ${ }^{\mathrm{I}}$

In conclusion, first, it is just not true that Frege and Russell are the only known influences on TLP. Even granting Carruthers' strict use of "know", Hertz, at least, must be accounted as one of these influences. Second, it is inappropriate to translate the general praise for Frege and/or Russell in the acknowledgements into support for specific doctrines in the text without specific warrant. Third, and most important, the view that the acknowledgements single out Frege in particular as the paramount influence on the doctrines of TLP is based on a misleading translation of the German text. ${ }^{\text {is }}$ On a balanced reading,

${ }^{2}$ McDonough, The Argument of the "Tractatus" (Albany, N.Y.: State U. New York P., 1986), p. 146).

3 N. Malcolm, Memory and Mind (Ithaca, N.Y.: Cornell U.P., 1977), pp. I43-50; McDonough, pp. I48-9, I58, etc.).

14 Carruthers takes special pains to exclude Hertz from the infuences on the doctrines of TLP: "Wittgenstein may have been influenced by the form but not the detailed content of Hertz" (Tractarian Semantics, p. 9). His only support is a reference to Griffin, Chap. 8). However, Griffin's point is quite the opposite (see Wittgenstein's Logical Atomism, pp. 5, 99). And see L. Goddard and B. Judge, The Metaphysics of Wittgenstein's Tractatus (Bundoora, Victoria: Australian Assoc. of Philosophy, 1982), and Wittgenstein's Notebooks, p. 36

is Russell concludes his Language, Mind and Matter with the observation that the psychologists, who "derive their inspiration from biology and physiology, have thrown a flood of light on the conception of meaning", and this is "indispensable to the student of logic" (Papers 9: 406). It is true, of course, that Russell often argued against confusing psychology with logic (e.g., "The Nature of Inference", ibid., p. 85). Now Russell might just be inconsistent. Or one may require certain distinctions. For example, in his Analysis of Mind he defines psychology as "the science of certain causal laws, which are different from those of e.g., physics or chemistry" (ibid., pp. 13, 15). So when he argues against psychologism in logic, he is not arguing against all relation of logic to psychology - but, roughly, against the view that logical laws are causal laws. Elsewhere, in Language, Mind, and Matter, he stresses that "The proposition as a particular psychological occurrence of course has constituents", and explains that the difference between logic and psychology is that logic abstracts between the differences between these different occurrences of the proposition (p. 158). It would be fallacious 
both Frege and Russell will receive ample representation, but this can, and should, be based on the actual text, not on a mythology built on an English translation. ${ }^{16}$

to infer that there is not something common to all of these propositions as-psychological-occurrences. That common element (a form?) belongs, in a sense, to both logic and psychology. This is not the importation of psychology to logic, but is more the reverse, namely, the introduction of logical considerations into the foundations of psychology (see McDonough, The Arguments of the "Tractatus", pp. 170, 183, etc.; "Wittgenstein's Clarification of Hertzian Mechanistic Cognitive Science", History of Philosophy Quarterly, II (1994): 219-35; and “Wittgenstein's Reversal on the 'Language of Thought' Doctrine", Philosophical Quarterly, 44 (1994): 482-94.

${ }^{16}$ On Black's view, the relation of the Tractatus to both Frege and Russell, involving numerous complicated agreements and disagreements with both, is too complex to be fruitfully distilled into any simplistic formula (see M. Black, A Companion to Wittgenstein's Tractatus [Ithaca: Cornell U.P., 196I], esp. pp. I-5, etc.). 